Catastrophe

IN THE MAKING 



\section{Catastrophe in the}

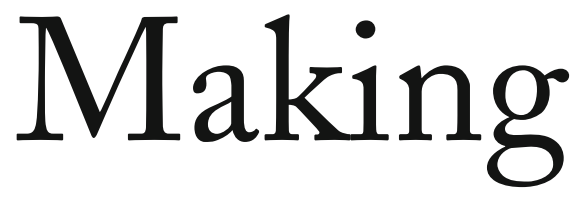

\section{The Engineering of Katrina and the Disasters of Tomorrow}

William R. Freudenburg

Robert Gramling

Shirley Laska

Kai T. Erikson

OislandPress / Shearwater Books

Washington | Covelo | London 


\section{A Shearwater Book \\ Published by Island Press}

Copyright (C) 2009 William R. Freudenburg, Robert B. Gramling, Shirley B. Laska, and Kai T. Erikson

All rights reserved under International and Pan-American Copyright Conventions. No part of this book may be reproduced in any form or by any means without permission in writing from the publisher: Island Press,

I718 Connecticut Ave., NW, Suite 300, Washington, DC 20009.

Shearwater Books is a trademark of The Center for Resource Economics.

Library of Congress Cataloging-in-Publication Data Freudenburg, William R.

Catastrophe in the making : the engineering of Katrina and the disasters of tomorrow / William R. Freudenburg, Robert B. Gramling, Shirley B. Laska.

p. cm.

Includes bibliographical references and index. ISBN-I3: 978-I-59726-682-6 (cloth : alk. paper) ISBN-IO: I-59726-682-5 (cloth : alk. paper)

1. Hurricane Katrina, 2oo5. 2. Hurricane protection-Louisiana-

Evaluation. 3. Flood control-Louisiana-New Orleans-Evaluation.

4. Levees-Louisiana-New Orleans-History. 5. Levees-Mississippi

River. 6. Emergency management-Louisiana-New Orleans. 7. Economic development-Environmental aspects-Louisiana-New Orleans.

I. Gramling, Robert B. II. Laska, Shirley Bradway, I944- III. Title. HV636 2005 .N4 F74 $2009 \quad 363 \cdot 34^{\prime} 92209760905 \mathrm{II}-\mathrm{dc} 22$ 2009021516

British Cataloging-in-Publication data available.

Printed on recycled, acid-free paper 4

Design by David Bullen

Manufactured in the United States of America

\begin{tabular}{|c|}
\hline \\
\hline \\
\hline \\
\hline $\begin{array}{lll}0 & 9 & 8\end{array}$ \\
\hline
\end{tabular}

Keywords: Army Corps of Engineers, Federal Emergency Management Agency (FEMA), Mississippi River GulfOutlet (MRGO), natural hazards, environmental justice, city planning, wetlands, floodwall, storm surge 


To all who have suffered

needlessly from "natural" disasters, and to future citizens

who may not need to suffer if we begin to act now. 



\section{- Contents -}

Prologue The First Days of Katrina 3

Chapter I A Mighty Storm Hits the Shore $\quad 15$

Chapter 2 The Setting $3 I$

Chapter 3 Slicing Through the Swamps 45

Chapter 4 The Growth Machine Comes to New Orleans 55

$\begin{array}{lll}\text { Chapter } 5 \text { A "Helpful Explosion" } & 67\end{array}$

Chapter 6 The Collapse of Engineered Systems $9 I$

Chapter 7 The Loss of Natural Defenses III

Chapter 8 Critical for Economic Survival?

Chapter 9 The Axe in the Attic $\quad 147$

Chapter io The End of an Error? $\quad{ }_{16}$

Endnotes $\quad I 7 I$

References $\quad 183$

Acknowledgments $\quad 197$

Index $20 I$ 
